\title{
Capital Structure and Board Characteristics in Firm Performances of Indonesian LQ45 Companies
}

\author{
SAARCE ELSYE HATANE* \\ FELICIA WIYONO \\ JOSUA TARIGAN
}

Accounting Department, Faculty of Business and Economics, Universitas

Kristen Petra

\begin{abstract}
This study aims to examine the effects of capital structure, and board characteristics toward the performance of the company measured through ROCE and EVA spread. The study is conducted on companies from various industries that are listed on the Indonesia Stock Exchange (in the LQ45 index) and published an annual report for seven years from 2010 to 2016. Capital structure management and the diversity in board characteristics must be well managed so that the company can sustain and secure its position in the market in order to maximize shareholders' wealth, which becomes a new corporate paradigm for the company. This study observes a total of 588 annual reports comprising 84 companies from various industries for seven years. Total debt to total asset ratio is used for capital structure measure as an independent variable. Firm performances are assessed through ROCE as accounting profit measure, and EVA spread as the market-based. There are three control variables, namely, sales growth, firm size, and firm age. There are eight hypotheses to be tested in this study. The results of this study are quite diverse. Debt to total assets has significant negative impacts on ROCE and EVA. The percentage of females on the board has no significant effect on ROCE but has a negative one on EVA. The number of board members who have doctoral level also has no significant impact on ROCE but has a significant positive effect on EVA. The business education background on the board has a significant negative effect on ROCE but has no significant influence on EVA. In addition, this study also tries to examine the board characteristics as moderating variables. The percentage of females on the board is weakening the negative influence of capital structures on EVA. In contrast, the percentage of doctoral degrees is able to strengthen the negative influence of capital structures on ROCE and EVA. Besides, the business education background is strengthening the negative impact of capital structures on EVA, but weakening the negative impact of capital structures on ROCE. Future studies may expand the results by examining the research framework, particularly in each industry, and add more characteristics of the boards.
\end{abstract}

Keywords: capital structure, female in the boards, boards' education level, business background diversity.

Abstrak- Penelitian ini bertujuan untuk menguji pengaruh struktur modal dan karakteristik board terhadap kinerja perusahaan yang diukur melalui ROCE dan EVA

*Corresponding author: elsyehat @ petra.ac.id 
spread. Studi ini dilakukan pada perusahaan dari berbagai industri yang terdaftar di Bursa Efek Indonesia (dalam indeks LQ45) dan menerbitkan laporan tahunan selama 7 tahun dari 2010 hingga 2016. Struktur modal dan keberagaman dalam karakreristik board harus dikelola dengan baik sehingga perusahaan dapat mempertahankan dan mengamankan posisinya di pasar untuk memaksimalkan kekayaan pemegang saham yang menjadi paradigma perusahaan baru bagi perusahaan. Studi ini mengamati total 588 laporan tahunan yang terdiri dari 84 perusahaan dari berbagai industri selama 7 tahun. Rasio debt total asset digunakan untuk ukuran struktur modal sebagai variabel independen. Kinerja perusahaan dinilai melalui ROCE sebagai ukuran laba akuntansi dan penyebaran EVA sebagai berbasis pasar. Ada tiga variabel kontrol, yaitu, pertumbuhan penjualan, ukuran perusahaan dan umur perusahaan. Ada delapan hipotesis yang akan diuji dalam penelitian ini. Hasil penelitian ini cukup beragam. Debt to total assets memiliki dampak negatif yang signifikan terhadap ROCE dan EVA. Jumlah anggota wanita dalam board tidak memiliki efek signifikan pada ROCE tetapi memiliki efek negatif pada EVA. Jumlah anggota dewan yang memiliki gelar doktoral juga tidak memiliki dampak signifikan pada ROCE tetapi memiliki efek positif yang signifikan terhadap EVA. Latar belakang pendidikan bisnis memiliki efek negatif yang signifikan pada ROCE tetapi tidak memiliki pengaruh signifikan terhadap EVA. Penelitian ini juga menguji peranan karakteristik board sebagai variable moderasi. Persentase jumlah wanita dalam board memperkuat pengaruh negatif capital structure terhadap ROCE dan EVA; sementara persentase jumlah doctoral level dalam board memperkuat pengaruh negatif capital structure terhadap ROCE dan EVA. Selain itu, latar belakang pendidikan bisnis memperkuat dampak negatif capital structure terhadap EVA, namun memperlemah dampak negatif capital structure terhadap ROCE. Penelitian selanjutnya dapat mengembangkan hasil penelitian ini dengan melakukan pengujian secara spesifik pada industri tertentu, dan menambah karakteristik board lainnya.

Kata Kunci: capital structure, female in the boards, boards' education level, business background diversity.

\section{Introduction}

Good corporate governance and capital structure have vital roles in the maintenance of a firm's performance. A country may be subjected to a crisis without good corporate governance. For instance, a financial crisis possibly will arise when several firms become too leveraged or have a high level of short-term debt due to weak corporate governance performances and inappropriate financing decisions (Detthamrong et al., 2017). Those regional financial problems may influence global 
economies; thus, the weightiness of long-term accomplishment of corporate governance and sound capital structure management is highlighted.

The disperser of shareholders and the inability to directly control and monitor managers' actions may result in a less satisfactory performance by a firm. To ensure that managers act in the best interest of shareholders is the purpose of corporate governance, and it can also diminish the information asymmetry between managers and shareholders by forcing managers to reveal important information. According to García-Sánchez et al. (2017), the firm's corporate governance practices are classified into two mechanisms, which are external and internal. Some examples of internal corporate governance mechanisms are board diversity, board composition, and board size (Tsai \& Tung, 2014). Among the board characteristics, board diversity has become a primary concern within corporate governance (García-Meca et al., 2015). Board diversity consists of observable diversity, such as gender, race, and age. Besides that, the non-observable (cognitive) diversity, such as education, functional background, and organizational tenure, are also important. Cognitive diversity is believed to expand the management's informational resources and improve problem-solving competence. Thus, to create a superior team of board, the observable diversity needs to be associated with the nonobservable ones.

According to Baran (2017), previous researches have been using companies with high liquidity and capitalization to assess firm performance. Baran (2017) stated that performance could be enhanced with the awareness of shareholders of the companies' inclusion in the S\&P 500 Index in the US. Besides that, companies included in FTS Euro 300 index in Europe and FTSE 350 index in the UK, which are similar to the S\&P index is also perceived to have a superior image in the stakeholders' perspective. For instance, a creditor may be more willing to give more debt because the companies are viewed as more credible than those not in the index since the companies included are the most liquid in terms of the most traded share in the market. Since the companies are superior in the market's view, likely there will be better control and quality of corporate governance compared to companies that are not included in the index. 
LQ45 index is chosen as the research subject as it is similar to the S\&P 500 index in the United States from the Indonesian index. The companies listed in the LQ45 index have the highest transaction value and market capitalization. As the maximization of shareholders' wealth is fast becoming a key instrument as a new corporate paradigm, decisions regarding capital structure management and board diversity should be well established for sustainable existence in the market. Thus, the study focused on capital structure management and board diversity, which is one of the crucial areas of concern, will be conducted. This research is done to look at the link between capital structure, board characteristics, and firm performances on companies listed in the LQ45 index. The research problems in this study are: 1) do the capital structure, and board characteristics affect the profitability and firm's value? 2) do board characteristics have an interaction effect on the firm's profitability and value? Moreover, this study is structured as follows: Section 2 reviews the literature and the preparation of a set of hypotheses; section 3 explains the details of the research method; section 4 describes research results, and section 5 concludes the study.

\section{Theoretical Framework and Hypothesis Development}

\subsection{The Theoretical Background}

There are three main underpinning theories as to the background in this study, and those are agency theory, trade-off theory, and pecking order theory. The existence of separation of control and ownership develop conflict between manager and shareholder as managers are likely to try to maximize their own benefit rather than the value of the firm and the separation of control and ownership also led to an imbalance of information. The issuance of debt may reduce the agency cost and affect a firm's performance by encouraging the managers to act in the best interest of shareholders instead of involving themselves in discretionary behavior (Dawar, 2014). The conflict arises from the agency problem show the need for corporate governance code in the first place, which also lead to the most optimal financing decision for the company (ACCA 
Global, 2018). It is believed that effective board monitoring can lessen the misallocation of funds, and so will improve shareholder's value (Isidro \& Sobral, 2014).

Pecking order theory resulted from asymmetric information. It was claimed that according to the theory, internal finance is preferred to be used first. Examples of internal finance are retained earnings and excess liquid assets. When internal financing is not sufficient, then firms may or may not acquire external financing to subsidize investment projects. If external financing is chosen, the usage of debt leverage, issuance of preferred stock, and lastly, followed by the issuance of common stock is preferred by managers of firms to lessen the further cost of asymmetric information (Nassar, 2016). The theory claimed that there is no search for an optimal capital structure. Companies just keep up a certain pecking order for their financing decision that allow them to bring up finance in the most efficient manner. The order of the financing structure is first by using all retained earnings available as it has no issue cost because companies already have the fund, issuing debt as it will only incur the moderate cost and last followed by the issuance of equity because it will incur a high level of issue cost (ACCA Global, 2018).

The trade-off theory suggested an optimum debt level considered in balancing the tax savings benefit of debt and bankruptcy cost. The theory also argued that the benefit to leverage only limited to when the optimal capital structure is reached by a firm ( $\mathrm{Vo}_{\mathrm{o}}$ \& Ellis, 2017). According to the theory, in order to achieve the maximum benefits from the interest tax shield, firms select the optimal mixture of debt in their capital structure. The firms' optimal capital structure incorporates the trade-off among the influences of firm and agency cost, bankruptcy cost, and personal taxes. It is expected that in order to attain balance among the benefits from interest tax shields with cost concerning current financial inflexibility or future financial difficulty, firms choose the level of debt (Nassar, 2016).

\subsection{Firm Performance}

Literature utilizes the various measurement of a firm's performance. It includes accounting-based measurement calculated from a firm's financial statement, which 
commonly used such as ROA and ROE align with previous studies from Salim \& Yadav (2012); Dawar (2014); Strom et al. (2014). Another research by Nirajini \& Priya (2013) also utilized ROCE, gross profit margin, net profit margin as the accounting measures aside from ROA and ROE. Accounting values are the measurement of the short-term operating performance of the firm. It concerned more about the profitability of the firm. Profitability is the ability of a firm to make a profit using all of its capital. According to Ehi-Oshio et al. (2013), profitability is the indicator of how effective a firm is utilizing its funds and assets available to be a profit. They also added that profitability enables the company to be stable in the business environment. Therefore, it can be concluded that profitability is the company's ability to earn profit through utilizing its assets to maintain its stability.

However, the usage of traditional performance measures has been gaining critiques due to their inability to integrate the full cost of capital over the last few years (Alipour $\&$ Pejman, 2015). According to the research done by Siddiqui (2015), accounting values are frail to manipulation and may possibly create distortion. On the contrary, modelbased market values are more relevant in particular circumstances as market prices are harder to be manipulated and easier to be verified. The firm's market values display the long-term value of the firm. It was also stated that managers should base their decisions to increase the total long-run market value of the firm instead of solely increasing the profit (Siddiqui, 2015). Examples of popular measurements for firm value include aside from Tobin's Q are Economic Value Added (EVA) and Market Value Added (MVA).

Profitability is the ability of a firm to make a profit using all of its capital. According to Ehi-Oshio et al. (2013), profitability is the indicator of how effective a firm is utilizing its funds and assets available to be a profit. Following earlier studies by Alipour \& Pejman (2015) and Nirajini \& Priya (2013), the profitability will be assessed using ROCE. The return on capital employed assesses the return gained from the capital invested in the business. By investing in the company, investors faced with a risk. Therefore, a return on capital is essential as a reward for the investors. The return should be compared between a comparable investment with similar risk, and the higher the 
ROCE figure is preferred by investors (ACCA Global, 2018).

Together with ROCE, market-value based measures are used, namely EVA. The value-added economic approach is a performance measurement metric. EVA is the remaining of the residual income derived from the subtraction of additional charge from net operating profit after tax (NOPAT). Stern Stewart and Company originally popularized the concept of EVA spread in the 1980s, and EVA spread takes into account the full cost of capital as well as the cost of equity. EVA strives to seize the true economic profit of a company and is calculated with the following formula where EBIT is the earnings before interest and tax (Alipour \& Pejman, 2015). The usage of EVA spread as a performance indicator follows previous studies from Bahri et al. (2011) and Alipour \& Pejman (2015).

\subsection{Capital Structure and Firm Performances}

Capital structure points to the method of an organization is financed by a composite of long-term capital (common shares and reserves, preference stocks, debentures, bank loans, and convertible loan stock) and short terms liabilities such as a bank overdraft and trade creditors (Nirajini \& Priya, 2013). In parallel with previous researches from Gill et al. (2011), Salim \& Yadav (2012), financial leverage was assessed in the studies by three ratios, which are the short-term debt to total assets, long-term debt to total assets and total debt to total assets ratio. However, this study deploys total debt to total assets ratio as the measurement of financial leverage, since it represents the total of long-term debt and short-term debt to the total asset ratio. Issuance of new debt will increase the capital employed owned by a firm, thus more capital which can be invested also increase and can lead to the addition of a firm ability to generate more sales. If the firm can manage its operating expense properly, the firm can generate a higher return on capital employed. Companies sometimes have a surplus of cash, and it is believed to be temporary. While companies have an excess of cash, they should invest or return it to shareholders (ACCA F9, 2016). With their surplus in cash, the company can either pay out debt or enhance investment activity. Those will contribute to lower debt to asset 
ratio as the company now has less debt and more assets from the payment of debt and the investment.

Previous studies conducted by Gill et al. (2011), Nirajini \& Priya (2013), Sultan \& Adam (2015) discovered that there is a favorable impact of debt asset ratio on profitability, which means that the firm is more profitable when it has more debts. As higher financial leverage or lower equity capital is linked with better firm performance. Firms with higher financial leverage are likely to demonstrate better than a firm with lower leverage. It is due to the close monitor of the firm's behavior from the creditor, which will possibly lead to better investment projects, for instance, through more discipline investment screening procedures (Detthamrong et al., 2017). Thus, it leads to the formation of the following hypothesis:

H1: Capital structure has a positive impact on firm profitability.

Based on the previous study done by Amaravathi \& Raja (2014) found that there is an adverse influence of the debt asset ratio on EVA spread. Thus, lower debt will generate higher economic value added. When a company has excess cash on hand, it can decide whether to pay for debt or invest in an asset, which will lead to lower debt and higher asset or smaller debt to asset ratio. Lower debt means lower invested capital within the firm and aligns with the formula to calculate the value-added economic figure will show higher economic value added. Therefore, the hypothesis is as follow: H2: Capital Structure has a negative effect on firm value.

\subsection{The Diversity in Board Characteristics and Firm Performances}

Corporate governance outlines the framework to form a transparent, accountable, and trustworthy environment. Corporate governance deals with agency problems due to the separation of managers (agents) and shareholders. It is an important tool to minimize conflict between agents, which may affect a firm's capital structure. A firm with strong corporate governance have better performance compared to weak governance firm, and weak governance firm tends to be more significantly leveraged. It also provides a way 
to settle disputes between agents and investors to make sure that agents manage funds in order to maximize the firm's value (Detthamrong et al., 2017).

According to García-Sánchez et al. (2017), the firm's corporate governance can be classified into two mechanisms, which are internal and external. One of the components of the internal corporate governance mechanism is board diversity. Board diversity can be classified into the observable diversity and age of the non-observable (cognitive) diversity. A more diverse board is believed to provide companies with more perceptive ideas and a substantial outlook and bring more set of skills into the company. Thus, this study concentrates on the internal corporate governance mechanism, particularly the composition of female members on the board, as well as members with the doctoral degree.

The BOC gender is measured as the ratio of the number of female commissioners to the number of all board of commissioners following some previous researches by Strom et al. (2014); Detthamrong et al. (2017) and Adusei et al. (2017). Earlier studies conducted by Anderson et al. (2016) and Fidanoski et al. (2014) found that there is a positive relationship between gender diversity and firm performance measured by accounting profit and firm value. More females on the board may enhance firm performance. Thus, it leads to the creation of the following hypothesis:

H3: Female board members have a positive impact on firm profitability.

H4: Female board members have a positive impact on firm value.

For the education level diversity, according to previous research by Anderson et al. (2016), educational attainment board' members (often measured by the existence of the $\mathrm{Ph} . \mathrm{D}$. degree) is measured as the ratio of the number of commissioners with a doctoral degree to total members in the board of commissioners. While for the education background diversity, the BOC background variable will measure how many members of the board of commissioners have finance, accounting, or economic background in education or a degree in MBA. The BOC background is assessed as the ratio of the number of commissioners with a finance background to total members in the board of 
commissioners. Following the previous study conducted by Fidanoski et al. (2014), better qualifications of a board member will also enhance competitive and firm performance through professional expertise and insight and also will ensure the existence of effective board with a high level of intellectual ability and critical judgment. Therefore, the following hypotheses are formed:

H5: The doctoral degree on the board has a positive impact on firm profitability.

H6: The doctoral degree on the board has a positive impact on firm value.

H7: The board education background in business and accounting has a positive impact on firm profitability.

H8: The board education background in business and accounting has a positive impact on firm value.

2.5 The Diversity in Board Characteristics, Capital Structure, and Firm Performances

The social heterogeneity in the board, including gender and educational background, may enhance monitoring and promote a more comprehensive decisionmaking process (Hillman, 2015). It can position the diversity of board gender and educational background to be moderating variables in the influence of capital structures on firm performances. The debtholders consider that the quality of corporate governance mechanism my control the manager's opportunistic behavior, and regard that the heterogeneity in the board composition as a reliable source of assurance of the firm's economic performances (Usman et al., 2019). Regarding leverage, funding in debts is more favorable. Female directors tend to use less debt or external financing since they are more risk-averse (Faccio et al., 2016). When external financing is needed, women's representation in the board can make the lenders charge fewer costs for the debts (Usman et al., 2019; García-Sánchez et al., 2017); thus, it can improve the firm's financial performances. Diversity in the board, such as higher education level and business, finance education background, increases the board's monitoring and supervision functions (Hillman \& Dalziel, 2003). The diversity certainly gives impact to the composition of the debt in the financing structure, as well as in the monitoring of 
the capital in improving the financial performances. Therefore, the following hypotheses are formed:

H9: Female board members have a moderating effect on the influence of capital structure on firm profitability.

H10: Female board members have a moderating effect on the influence of capital structure towards firm value.

H11: The doctoral degree on the board has a moderating effect on the influence of capital structure on firm profitability.

H12: The doctoral degree on the board has a moderating effect on the influence of capital structure on firm value.

H13: The board education background in business and accounting has a moderating effect on the influence of capital structure on firm profitability.

H14: The board education background in business and accounting has a moderating effect on the influence of capital structure towards firm value.

\section{Research Method}

Based on the earlier background and theory, the relationship between capital structure and board diversity toward firm performance is going to be observed. Board diversity is expected to be the moderating variable between capital structure and firm performance. Thus, this study is looking at the interaction between capital structure and board diversity and its influence on capital structure toward firm performance.

This model includes the determinants affecting firm performance. Firm performance is measured through profitability by return on capital employed, and firm value by economic value-added spread. The independent variables are capital structure and board characteristics. Capital structure is determined through Debt to Total Asset Ratio (DTA), and board diversities are derived from BOC Gender (BOCG), BOC education level (BOCLVL), and BOC educational background (BOCBA). The board 
characteristics are also tested as moderating variables. Sales growth (GROWTH), firm size (SIZE), and firm age (AGE) are the control variables for this study.

This study examines two multiple linear regression model to test the correlation of the independent variables of capital structure, and moderating variables are the board diversity components, that will be impactful to the change of dependent variable, which is the firm performance.

This formula can represent the model:

Model 1:

Model 2:

$$
\begin{aligned}
\text { OOCE }_{i t}=\beta_{0} & +\beta_{1} D T A_{i t}+\beta_{2} \text { BOCG }_{i t}+\beta_{3} \text { BOCLVL }_{i t}+\beta_{4} \text { BOCBA }_{i t} \\
& +\beta_{5} D T A * B O C G_{i t}+\beta_{6} D T A * B O C L V L_{i t} \\
& +\beta_{7} D T A * B O C B A_{i t}+\beta_{8} G R O W T H_{i t}+\beta_{9} S I Z E_{i t} \\
& +\beta_{10} A G E_{i t}+\varepsilon_{i t}
\end{aligned}
$$

Explanation:

$$
\begin{aligned}
E V A_{i t}=\beta_{0}+ & \beta_{1} D T A_{i t}+\beta_{2} B_{O C C G_{i t}}+\beta_{3} B O C L V L_{i t}+\beta_{4} B O C B A_{i t} \\
& +\beta_{5} D T A * B O C G_{i t}+\beta_{6} D T A * B O C L V L_{i t} \\
& +\beta_{7} D T A * B O C B A_{i t}+\beta_{8} G R O W T H_{i t}+\beta_{9} S_{I Z E_{i t}} \\
& +\beta_{10} A G E_{i t}+\varepsilon_{i t}
\end{aligned}
$$

ROCE $_{\text {it }}=$ Return on Capital Employed of $i$ company in $t$ period

$\mathrm{EVA}_{\text {it }}=$ Economic Value-Added spread of $i$ company in $t$ period

DTA $_{\text {it }}=$ Debt to Asset of $i$ company in $t$ period

BOCG $_{\text {it }}=$ Gender diversity in Board of Commissioners of $i$ company in a period

BOCLVL $\mathrm{i}_{\mathrm{it}}=$ Education level in Board of Commissioners of $i$ company in $t$ period

BOCBA $_{\mathrm{it}}=$ Education background in Board of Commissioners of $i$ company in $t$ period

$\mathrm{DTA}^{*} \mathrm{BOCG}_{\mathrm{it}}=$ DTA times BOCG of $i$ company in $t$ period

$\mathrm{DTA}^{*} \mathrm{BOCLVL}_{\mathrm{it}}=\mathrm{DTA}$ times BOCLVL of $i$ company in $t$ period

$\mathrm{DTA}^{*} \mathrm{BOCBA}_{\mathrm{it}}=\mathrm{DTA}$ times BOCBA of $i$ company in $t$ period

GROWTH $_{\text {it }}=$ Sales growth of $i$ company in $t$ period

SIZE $_{\text {it }}=$ Firm size of $i$ company in $t$ period

$\mathrm{AGE}_{\mathrm{it}}=$ Firm age of $i$ company in $t$ period

$\beta_{0} \quad=$ Constant of the regression

$\varepsilon_{\text {it }} \quad=$ Error

$\beta_{1 .} \beta_{2}, \beta_{3}, \beta_{4}, \beta_{5}, \beta_{6}, \beta_{7}, \beta_{8}, \beta_{9}, \beta_{10}=$ Regression coefficient of each variable

The research framework is figured in Figure 1. The types of data used in this study are quantitative data and are panel data, which is a combination of time series and crosssection data. The operational definition of the variables is presented in Table 1. Cross- 
section data utilized in the research is the data from companies listed in the LQ45 stock exchange, which consisted of 84 companies from various types of industries. While for the time-series data, a period of 7 years from 2010-2016 is gathered. The total unit analysis is firm years, a total of 588 observations, as presented in Table 2 . The secondary data are obtained from Bloomberg, and some are obtained from the annual report.

Figure 1.

Research Model

$\mathrm{H} 1, \mathrm{H} 2$

$\mathrm{H} 3, \mathrm{H} 4$

H5, H6

$\mathrm{H} 7, \mathrm{H} 8$

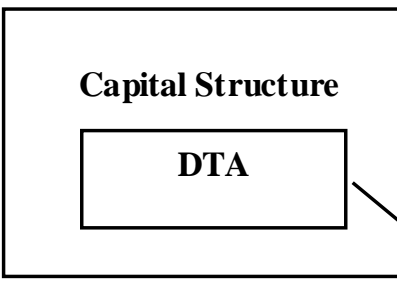

Corporate Governance (Diversity in Board of Commissioner)

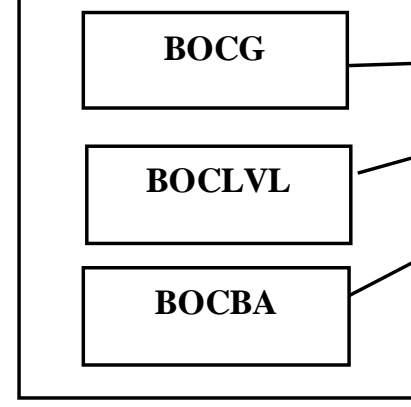

H9, H10

Moderating Variables

H11,

H12

H13, H14

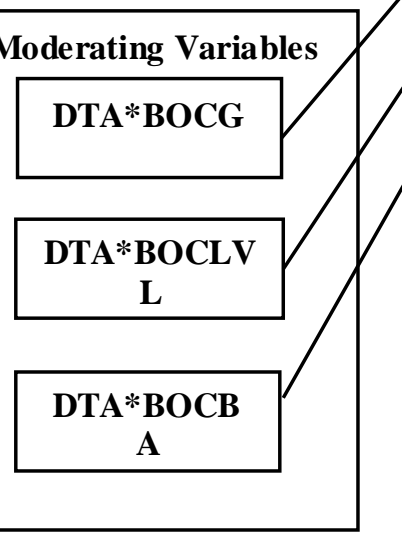

Firm Performances

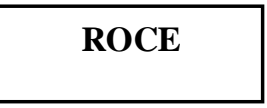

\section{EVA}

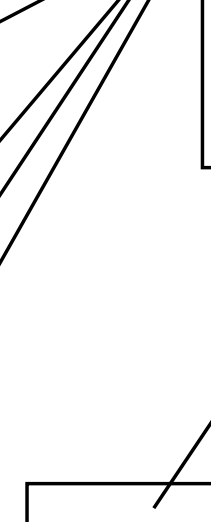

GROWT

H

SIZE

AGE

Control Variables 
Table 1.

Operational Definition

\begin{tabular}{|c|c|}
\hline Variables & Definition \\
\hline $\begin{array}{l}\text { Return on } \\
\text { capital } \\
\text { employed }\end{array}$ & $\begin{array}{l}\text { It illustrates the return gained from the capital invested in the business. } \\
\text { Following earlier studies by Alipour \& Pejman (2015) and Nirajini \& Priya } \\
\text { (2013), the formula is }\end{array}$ \\
\hline & Return on capital employed $(R O C E)=\frac{\text { EBIT }}{\text { capital employed. }}$ \\
\hline EVA spread & $\begin{array}{l}\text { The remaining of the residual income derived from the subtraction of } \\
\text { additional charge from net operating profit after tax (NOPAT) (Bahri et al., } \\
\text { 2011; and Alipour \& Pejman, 2015). } \\
\qquad E V A=\frac{\text { NOPAT }}{\text { invested capital }}-\text { WACC }\end{array}$ \\
\hline $\begin{array}{l}\text { Debt to } \\
\text { Total Asset }\end{array}$ & $\begin{array}{l}\text { Term to measure a company's ability to fulfill all its financial obligations } \\
\text { when the company is liquidated. Following previous research by Gill et al. } \\
\text { (2011), Sultan \& Adam (2015) and Nassar (2016), debt to the total asset as a } \\
\text { measurement of capital structure is used: } \\
\text { Debt to Total Asset }=\frac{\text { Total Debt }}{\text { Total Asset }}\end{array}$ \\
\hline BOCG & $\begin{array}{l}\text { The measurement of the number of female commissioners to the number of } \\
\text { all board of commissioners } \\
\text { BOC Gender }=\frac{\text { Number of female commissioner }}{\text { Total number of commissioners }}\end{array}$ \\
\hline BOCLVL & $\begin{array}{l}\text { The measurement of the number of commissioners with a doctoral degree to } \\
\text { the number of all board of commissioners } \\
\qquad B O C P h D=\frac{\text { Number of commissioner with doctoral degree }}{\text { total number of commissioners }}\end{array}$ \\
\hline BOCBA & $\begin{array}{l}\text { The measurement of the number of commissioners with a finance } \\
\text { background to the number of all board of commissioners } \\
\text { BOC Finance }=\frac{\text { Number of commissioner with finance background }}{\text { Total number of commissioners }}\end{array}$ \\
\hline
\end{tabular}

Table 2.

Sampling Criteria

\section{Sampling Criteria}

Numbers

Number of companies included in the LQ45 index between 2010 and 2016

Companies that did not publish a complete annual report in the required period

Companies which are not listed in IDX after 2010

Number of companies that fulfill the criteria and included a sample

Total samples observation ( 84 companies $\mathrm{x} 7$ years) 


\section{Results and Discussion}

\subsection{Statistic Results}

The descriptive analysis in this study summarizes the maximum value, minimum value, mean, and standard deviation. Table 3 represents the descriptive statistics of variable ROCE, EVA, Debt asset ratio (DTA), gender diversity (BOCG), education diversity (BOCLVL \& BOCBA), and also sales growth (GROWTH), firm size (SIZE) and firm age (AGE).

Based on Table 4, as the result of the estimation model test show that 2 out of 3 with a fixed-effect model for both regression models 1 and 2, the appropriate model is a fixed-effect model. According to the central limit theorem, the means of moderately large samples are mostly well-approximated by a normal distribution. Hence, the violation of the normality assumption is accepted (Solimun et al., 2017).

Table 3.

Descriptive Statistics

\begin{tabular}{lccccc}
\hline Variable & Mean & Median & SD. & Min & Max \\
\hline ROCE & 0.155 & 0.104 & 0.315 & $-3,321$ & 2,330 \\
EVA & -0.026 & -0.017 & 0.525 & $-8,398$ & 1.160 \\
DTA & 0.269 & 0.214 & 0.280 & 0 & 3,253 \\
BOCG & 0.075 & 0 & 0.119 & 0 & 0.6 \\
BOCLVL & 0.183 & 0.167 & 0.193 & 0 & 0.833 \\
BOCBA & 0.532 & 0.5 & 0.244 & 0 & 1 \\
GROWTH & 0.125 & 0.091 & 0.512 & -0.983 & 8,040 \\
SIZE & 13.244 & 13.211 & 0.600 & 11.125 & 15.016 \\
AGE & 15.485 & 16 & 8.157 & 1 & 40 \\
\hline
\end{tabular}

Feasibility tests and hypothesis tests are carried out using panel data regression with a significance level of $10 \%$. A model feasibility test is performed with the $\mathrm{F}$ test (simultaneous) to see whether the independent variable influence the dependent variable simultaneously. The regression test results in the determinant coefficient (R-square) of 9.5\% for ROCE and $11.8 \%$ for EVA. Table 5 provides the results of partial and 
simultaneous effects, including the determinant coefficient (R-square) and collinearity test for the research model.

Table 4.

Panel Effect Model Estimation

\begin{tabular}{|c|c|c|c|c|}
\hline $\begin{array}{l}\text { Regression } \\
\text { Model }\end{array}$ & Variable & Test & Test Result & $\begin{array}{l}\text { Panel } \\
\text { Model }\end{array}$ \\
\hline \multirow{3}{*}{1} & \multirow{3}{*}{ ROCE } & OLS & Fixed Effect Model (FEM) & \multirow{3}{*}{ FEM } \\
\hline & & LM & $\begin{array}{l}\text { Random Effect Model (FEM) } \\
\text { (p-value } 4.40355 \mathrm{e}-095)\end{array}$ & \\
\hline & & Hausman & $\begin{array}{l}\text { Fixed Effect Model (FEM) } \\
\quad(\mathrm{p} \text {-value } 0.000114863)\end{array}$ & \\
\hline \multirow{3}{*}{2} & \multirow{3}{*}{ EVA } & OLS & $\begin{array}{l}\text { Fixed Effect Model (FEM) } \\
(p \text {-value } 2.7802 \mathrm{e}-005)\end{array}$ & \multirow{3}{*}{ FEM } \\
\hline & & $\mathrm{LM}$ & $\begin{array}{c}\text { Random Effect Model (FEM) } \\
\quad(\mathrm{p} \text {-value } 0.00321342)\end{array}$ & \\
\hline & & Hausman & $\begin{array}{l}\text { Fixed Effect Model (FEM) } \\
\quad(p-\text { value } 1.11707 \mathrm{e}-005)\end{array}$ & \\
\hline
\end{tabular}

Table 5.

Regression Results Summary

\begin{tabular}{|c|c|c|c|c|c|}
\hline & \multirow{2}{*}{$\begin{array}{c}\begin{array}{c}\text { Collinearity } \\
\text { Tests }\end{array} \\
\text { VIF }\end{array}$} & \multicolumn{2}{|c|}{ ROCE } & \multicolumn{2}{|c|}{ EVA } \\
\hline & & Coefficient & $\mathrm{p}$-value & Coefficient & $\mathrm{p}$-value \\
\hline Const & & 1.05100 & 0.1376 & 1.13002 & 0.5053 \\
\hline DTA & 5.118 & -0.392399 & $<0.0001 * * *$ & -0.431861 & $0.0369 * *$ \\
\hline BOCG & 3.579 & -0.0102748 & 0.9578 & -1.55970 & $0.0009 * * *$ \\
\hline BOCLVL & 2.243 & 0.0317176 & 0.7903 & 0.573721 & $0.0453 * *$ \\
\hline BOCBA & 1.850 & -0.245413 & $0.0030 * * *$ & -0.00328811 & 0.9867 \\
\hline DTA*BOCG & 5.585 & 0.530003 & 0.3840 & 7.59997 & $<0.0001^{* * *}$ \\
\hline DTA*BOCLVL & 2.148 & -0.574616 & $0.0972 *$ & -1.59396 & $0.0552 *$ \\
\hline DTA*BOCBA & 7.673 & 0.429830 & $0.0030 * * *$ & -1.10458 & $0.0015^{* * *}$ \\
\hline GROWTH & 1.023 & -0.0466417 & $0.0123^{* *}$ & 0.121846 & $0.0065 * * *$ \\
\hline SIZE & 1.250 & -0.0411750 & 0.4690 & -0.107627 & 0.4301 \\
\hline AGE & 1.080 & -0.0104833 & $0.0428 * *$ & 0.0287755 & $0.0205^{* *}$ \\
\hline P-value (F-test) & & \multicolumn{2}{|c|}{$8.29 \mathrm{e}-71$} & \multicolumn{2}{|c|}{$1.62 \mathrm{e}-08$} \\
\hline $\begin{array}{l}\text { Determinant } \\
\text { Coefficient }\left(\mathrm{R}^{2}\right)\end{array}$ & & \multicolumn{2}{|c|}{0.095530} & \multicolumn{2}{|c|}{0.118794} \\
\hline $\begin{array}{l}\text { Heteroskedasticity } \\
\text { (p-value from chi- } \\
\text { square) }\end{array}$ & & \multicolumn{2}{|c|}{0.057554} & \multicolumn{2}{|c|}{0.05883} \\
\hline
\end{tabular}

Notes: statistical significance is at the following error levels: $* * *<1 \% ; * *<5 \% ; *<10 \%$ 
Table 6.

Hypotheses Test Results Summary

\begin{tabular}{|c|c|c|c|c|c|}
\hline $\begin{array}{c}\text { Hypothesis } \\
\text { No. }\end{array}$ & $\begin{array}{c}\text { Independent/ } \\
\text { Moderating } \\
\text { Variable }\end{array}$ & $\begin{array}{l}\text { Dependent } \\
\text { Variable }\end{array}$ & Hypothesis & $\begin{array}{l}\text { T-test Result } \\
\text { (T-Test Value) }\end{array}$ & Decision \\
\hline 1 & DTA & ROCE & Positive & $\begin{array}{c}\text { Negative } \\
\text { significant } \\
(-4.560 * * *)\end{array}$ & $\begin{array}{c}\text { Not } \\
\text { supported }\end{array}$ \\
\hline 2 & DTA & EVA & Negative & $\begin{array}{l}\text { Negative } \\
\text { significant } \\
(-2.092 * *)\end{array}$ & Supported \\
\hline 3 & BOCG & ROCE & Positive & $\begin{array}{c}\text { Insignificant } \\
(-0.05297)\end{array}$ & $\begin{array}{c}\text { Not } \\
\text { supported }\end{array}$ \\
\hline 4 & BOCG & EVA & Positive & $\begin{array}{c}\text { Negative } \\
\text { significant } \\
(-3.352 * * *)\end{array}$ & $\begin{array}{c}\text { Not } \\
\text { supported }\end{array}$ \\
\hline 5 & BOCLVL & ROCE & Positive & $\begin{array}{c}\text { Insignificant } \\
(0.2661)\end{array}$ & $\begin{array}{c}\text { Not } \\
\text { supported }\end{array}$ \\
\hline 6 & BOCLVL & EVA & Positive & $\begin{array}{c}\text { Positive } \\
\text { significant } \\
\left(2.007^{*}\right)\end{array}$ & Supported \\
\hline 7 & BOCBA & ROCE & Positive & $\begin{array}{c}\text { Negative } \\
\text { significant } \\
(-2.987 * * *)\end{array}$ & $\begin{array}{c}\text { Not } \\
\text { supported }\end{array}$ \\
\hline 8 & BOCBA & EVA & Positive & $\begin{array}{c}\text { Insignificant } \\
(-0.01668)\end{array}$ & $\begin{array}{c}\text { Not } \\
\text { supported }\end{array}$ \\
\hline
\end{tabular}

Notes: statistical significance is at the following error levels: $* * *<1 \% ; * *<5 \%$; $*<10 \%$ Table

The hypotheses test results are summarized in Table 6, showing the initial hypothesis and its relationship compared to the t-test result along with the decision whether the hypotheses are supported or not supported. The variance inflation factor (VIF) values in Table 5 are less than 10; it indicates that the regression models are free from collinearity problems. The p-values of chi-square in the heteroscedasticity test are higher than 0.05; thus, the models are supported for the homogeneity assumption.

From Table 5, it can be seen from the interaction between DTA and board diversity variables that BOCLVL and BOCBA can be moderating variables between DTA and ROCE as the p-value is below 0.1. Therefore, H11 and H13 are supported. While for the relationship between DTA and EVA, all of the interaction between DTA and board diversity shows a p-value below 0.1 , which means that BOCG, BOCLVL, and BOCBA 
are moderating the influence of DTA on EVA. Thus, H10, H12, and H14 are supported. The detailed results of moderating variables can be found in Table 7 .

Table 7.

Moderating Effect

\begin{tabular}{|c|c|c|c|c|}
\hline No. & $\begin{array}{c}\text { Independent and } \\
\text { Moderating } \\
\text { Variables } \\
\end{array}$ & $\begin{array}{l}\text { Dependent } \\
\text { Variables }\end{array}$ & Influences & Decision \\
\hline \multirow{3}{*}{1} & DTA & ROCE & $\begin{array}{c}\text { Negative } \\
\text { Significant }\end{array}$ & \multirow{3}{*}{$\begin{array}{l}\text { BOCG is failed to be } \\
\text { independent as well as } \\
\text { moderating variables }\end{array}$} \\
\hline & BOCG & ROCE & Insignificant & \\
\hline & DTA*BOCG (H9) & ROCE & $\begin{array}{c}\text { Insignificant } \\
(\text { T-test }=0.8713)\end{array}$ & \\
\hline \multirow{3}{*}{2} & DTA & EVA & $\begin{array}{c}\text { Negative } \\
\text { Significant }\end{array}$ & \multirow{3}{*}{$\begin{array}{l}\text { BOCG is succeeded in } \\
\text { being independent and } \\
\text { also moderating } \\
\text { variables. Its interaction } \\
\text { is reducing the negative } \\
\text { impact of DTA on EVA. }\end{array}$} \\
\hline & BOCG & EVA & $\begin{array}{l}\text { Negative } \\
\text { Significant }\end{array}$ & \\
\hline & $\begin{array}{c}\text { DTA*BOCG } \\
(\mathrm{H} 10)\end{array}$ & EVA & $\begin{array}{l}\text { Positive Significant } \\
(\text { T-test }=5.209 * * *)\end{array}$ & \\
\hline \multirow{3}{*}{3} & DTA & ROCE & $\begin{array}{c}\text { Negative } \\
\text { Significant }\end{array}$ & \multirow{3}{*}{$\begin{array}{l}\text { BOCLVL is a pure } \\
\text { moderating variable, } \\
\text { which strengthens the } \\
\text { influence of DTA } \\
\text { toward ROCE }\end{array}$} \\
\hline & BOCLVL & ROCE & Insignificant & \\
\hline & $\begin{array}{c}\text { DTA* BOCLVL } \\
(\mathrm{H} 11)\end{array}$ & ROCE & $\begin{array}{c}\text { Negative } \\
\text { Significant } \\
(\mathrm{T}-\text { test }=-1.662 *)\end{array}$ & \\
\hline \multirow[b]{3}{*}{4} & DTA & EVA & $\begin{array}{c}\text { Negative } \\
\text { Significant }\end{array}$ & \multirow{3}{*}{$\begin{array}{l}\text { BOCLVL is succeeded } \\
\text { in being independent } \\
\text { and moderating } \\
\text { variables. Its interaction } \\
\text { is increasing the } \\
\text { negative impact of DTA } \\
\text { on EVA. }\end{array}$} \\
\hline & BOCLVL & EVA & Positive Significant & \\
\hline & $\begin{array}{c}\text { DTA }^{*} \text { BOCLVL } \\
(\mathrm{H} 12)\end{array}$ & EVA & $\begin{array}{c}\text { Negative } \\
\text { Significant } \\
(\mathrm{T}-\text { test }=-1.922 *)\end{array}$ & \\
\hline \multirow{3}{*}{5} & DTA & ROCE & $\begin{array}{c}\text { Negative } \\
\text { Significant }\end{array}$ & \multirow{3}{*}{$\begin{array}{l}\text { BOCBA is succeeded in } \\
\text { being independent and } \\
\text { moderating variables. Its } \\
\text { interaction reduces the } \\
\text { negative impact of DTA } \\
\text { on ROCE. }\end{array}$} \\
\hline & BOCBA & ROCE & $\begin{array}{l}\text { Negative } \\
\text { Significant }\end{array}$ & \\
\hline & $\begin{array}{c}\text { DTA* BOCBA } \\
(\mathrm{H} 13)\end{array}$ & ROCE & $\begin{array}{l}\text { Positive Significant } \\
(\text { T-test }=2.980 * * *)\end{array}$ & \\
\hline \multirow{3}{*}{6} & DTA & EVA & $\begin{array}{c}\text { Negative } \\
\text { Significant }\end{array}$ & \multirow{3}{*}{$\begin{array}{c}\text { BOCBA is a pure } \\
\text { moderating variable. Its } \\
\text { interaction is increasing } \\
\text { the negative impact of } \\
\text { DTA on EVA. }\end{array}$} \\
\hline & BOCBA & EVA & Insignificant & \\
\hline & $\begin{array}{c}\text { DTA* BOCBA } \\
(\mathrm{H} 14)\end{array}$ & EVA & $\begin{array}{c}\text { Negative } \\
\text { Significant } \\
(\text { T-test }=2.980 * * *)\end{array}$ & \\
\hline
\end{tabular}

Notes: statistical significance is at the following error levels: $* * *<1 \% ; * *<5 \% ; *<10 \%$ 


\subsection{Discussion and Theory Explanations}

For hypothesis 1, the results show that capital structure measured through total debt to total asset ratio has a significant adverse influence on profitability measured by return on capital employed. This result is conformable to previous studies done by Singh (2013), Nassar (2016), Le \& Bich (2017). It was found that there was a significant negative influence from capital structures on profitability, as the higher the proportion of debt, the lower the profitability becomes. This outcome is conflict to the agency theory, which stated that an increase in debt could reduce agency problems as a higher level of monitor tends to result in better decisions and action by managers related to the decision on investment project, which in the long-term will increase the return to the shareholders. While the result is contradictory to agency theory, the finding is also in contrast with the trade-off theory but fit pecking order theory as debt financing is less preferred because strong covenant sticks to the use of debt, hence the usage of debt is not the first option in capital structuring decision (Hasan et al., 2014).

For hypothesis 2, the research results indicate that capital structure has a significant adverse effect on the firm value measured by EVA spread. This result matches the previous studies conducted by Vo \& Ellis (2017). This result is correspondence the agency theory that the issuance of debt can lower the agency cost; as more monitoring from the debt holder is present to ensure managers act in the best interest of the debt holder, thus better decision and action regarding the investment decision can be produced and create better value for the company. According to Vo \& Ellis (2017), debt holders will demand a higher interest rate when debt is high as compensation of higher risk of liquidation or the possibility of underinvestment. The higher cost of debt will increase the WACC and can lower EVA as a measurement of firm value in this research. Thus, related to this condition, debt does impact the company negatively.

For hypothesis 3 , as the number of females on board on Indonesian companies listed in LQ45 is relatively small, which can be seen from the mean value of only $7.5 \%$ compared to the number of percentages of female directors on board in Asia, which is 14\%. According to Groysberg et al. (2017), Asia has the lowest female representation 
as a board member. This might be the reason why the gender diversity on board variables formed an insignificant influence on firm performance as with only a few women on board, the benefit or the role of women is often not realized. For hypothesis 4 , this study shows that the heterogeneity in board structures has a negative impact on firm value, which is measured by EVA. This result confirms previous studies conducted by Bohren \& Strom (2010). These findings are consistent with social psychology argues that the presence of the minorities on board or female as part of the board member results in poor communication and cooperation (Isidro \& Sobral, 2014).

For hypothesis 5 , this result is contradictory to the previous study conducted by Fidanoski et al. (2014), where a positive correlation was found between board education levels with accounting-based measures. For hypothesis 6 , this result is similar to the previous study conducted by Anderson et al. (2016). The diversity of education level entitled to the board of commissioner members led to the enhancement of firm value. This result is consistent with the resource dependency theory, which stated that a more diverse board is the key resource to a company's success. The higher education level of board members can improve managerial decision making, which is, in turn, will give a positive impact on firm value.

For hypothesis 7, the result of the negative impact is in parallel with previous research done by Ness et al. (2010). The research concluded that having board members with finance background have a negative impact on revenue as they are considered to be more conservative and rigid to a new business opportunity. Board members with finance expertise are likely more sensitive towards risk that stockholders will suffer and more analytical, while revenue growth via market expansion often involves entrepreneurial skills and efforts.

For hypothesis 8, contradicting with resource dependency theory, Hu et al. (2017) argued that education is not a good proxy for board ability. However, education still holds an important function as an evaluation criterion for hiring and choosing a potential board. Thus, it can be seen that the board does not believe that that particular person's educational background caused failure from the previous member. 
The interaction influence test results show only H9, which is not supported. The existence of a female member on the board cannot modify the influence of capital structure in a firm's profit. However, the female members on the board and the education background (H13) may reduce the negative effect of using higher debts. The other hypotheses (H11, H12, and H14) are also supported in this study. The results show that the education expertise and experience have an impact on the influence of debt composition in the capital on the firm performances. Hillman \& Dalziel (2003), Faccio et al. (2016), Usman et al. (2019), and García-Sánchez et al. (2017) mentioned the role of diversity in board characteristics in the capital structures. At last, the productivity of managing capital structure has an impact on financial performances.

\section{Conclusion, Implication, and Limitation}

\subsection{Conclusion}

The primary objective of conducting this study is to obtain a better understanding regarding the capital structure decision and good practice of corporate governance towards firm performances. Furthermore, this study also observes and sees the ability of board diversity as a moderating variable in the influence of capital structure towards firm performances. The firm performances assessed through two indicators, which are the accounting measure by return on capital employed (ROCE) and firm value by economic value added (EVA). This study observes the influence of capital structure quantified through the total debt to total asset ratio (DTA) and board diversity of the board of commissioner components including gender diversity or women on board (BOCG), board's education level (BOCLVL), and board education background (BOCBA) towards firm performance.

The debt to asset ratio has a negative significant effect on both accounting measure (ROCE) and firm value (EVA). While, the moderating variable, BOCG, and BOCLVL have an insignificant influence on ROCE, and there is a significant negative influence from BOCBA towards ROCE. On the other hand, the relationship between the moderating variable and EVA show more variety of result. BOCG has a negative 
influence on EVA, while BOCLVL is favorable for EVA and different from the other two, BOCBA has an insignificant impact on EVA.

For the effects of the control variables toward firm performance, the result generated also varies. GROWTH and AGE have a negative significant impact on ROCE, while SIZE has an insignificant influence on ROCE. Contrasting with the result towards ROCE, GROWTH, and AGE have a positive significant influence on EVA and the insignificant impact of SIZE on EVA.

\subsection{Implication}

The board diversity components have the following implication on the company's financing policy. The gender diversity on board of commissioners shows that it failed to be a moderating variable. The existence of women on board does not have any impact on the company's capital structuring policy shown through the debt policy toward accounting profit (ROCE). The reason might be caused by a few numbers of women on board in the LQ45 companies with an average of only 7.5\%. However, the gender diversity on board actually can affect the market value-based measure (EVA). This indicates, the more women included as a board member, the lower impact the debt has on firm value. Hence, to ease out the impact of debt toward firm value, more women should be added on board as women are perceived as more risk-averse than men, thus can provide thorough advice of financing policies.

Having more people with a doctoral degree as a board member improves the company's capital structuring decision. The company can further improve both ROCE and EVA by hiring more board members with a doctoral degree as they can influence the debt policy of the company and can advise the company to choose appropriate financing options to improve firm performance at the best possible cost to maximize the long-term interest of stakeholder.

Having more people from an accounting or finance background can aid in lessening the impact of poor debt financing on accounting measures (ROCE). The board member with a finance background can assist by advising on debt issuance. However, having more members with a finance background will not directly aid the company's firm value 
measured by EVA. However, they can help by providing advice on debt making in order to maintain the company's reputation and creditworthiness in the creditors' point of view and will create better value for the company.

As debt and firm performance have a converse relationship, it is better to put more attention towards capital structuring decision to adopt as few as possible debt as a way of company's financing in order to improve firm performance, both in short-term accounting measure through ROCE and the long-term market value-based measure through EVA. However, for the board diversity factor, as some of the results generated show insignificant influence, it is recommended for the companies to also pay more attention in managing and implementing board diversity in their companies not only from the perspective of some people hired but also from the quality of the board member as the quality is more important than quantity. It is crucial and important for the stakeholders to have a decent and sound understanding of how the company manages its capital structure and the impact of the capital structure on firm performance. Thus, more attention and deepening of knowledge put on this topic by the stakeholders are suggested.

This study contributes to the empirical studies in corporate governance, especially about the diversity in corporate governance characteristics. The presence of female members on the board of commissioners and board members who have educational backgrounds in business, economics, accounting, and finance, can reduce the level of risk of the company when the company must use external funding. The negative influence of debts on the economic value of a company can decrease with the presence of these two diversities of characters. The supervisory and expertise functions of the board in managing capital can increase the value of the company by controlling capital costs. An increase in EVA value indicates that the company's ROCE is higher than the WACC.

\subsection{Limitation}

During the research of this study, some limitations are encountered and explained below. This limitation can be a reference for future research. This research is not 
specified in one particular industry. Instead, it was done on LQ45 from various industries. Therefore, the result may not be as accurate if the research is conducted in a specific industry to compare the trend due to the differentiation of the business environment, and the company's strategy as a result only represent companies that are included in the LQ45 index, not Indonesian's firm in general. This research found the small level of correlation between the independent variable and dependent variable (both ROCE and EVA) with the value of both below 50\%, which means that many other factors outside this research can influence the dependent variables.

Based on the stated limitation, the following suggestions are made. Future studies may try to look for the impact of capital structure on firm performance from a specific industry and compare the result so that the real picture of the influence can be observed. Further study can be conducted by using different independent variables such as net profit margin or gross profit margin to find out whether the capital structure has the same or different impact on the dependent variables since the dependent variables utilized in this research are not common to be used.

\section{References}

ACCA F9. (2016). ACCA Paper F9Financial Management (9th ed.). London: BPP Learning Media Ltd.

Adusei, M., Akomea, S., \& Poku, K. (2017). Board and management of gender diversity and financial performance of microfinance institutions. Cogent Business \& Management, 4(1), 1-14. doi: 10.1080/23311975.2017.1360030

Alipour, M., \& Pejman, M. (2015). The impact of performance measures, leverage, and efficiency on market value added: Evidence from Iran. Global Economics and Management Review, 20(1), 6-14. doi: 10.1016/j.gemrev.2015.04.001

Amaravathi \& Raja, A. (2014). Optimum Capital Structure Strategies and Usage of Economic Value Added for Share Holders' Value Creation with Special Reference to Infosys. Indian Journal of Applied Research, 4(12), 556-558.

Anderson, R., Reeb, D., Upadhyay, A., \& Zhao, W. (2011). The Economics of Director Heterogeneity. Financial Management, 40(1), 5-38. doi: 10.1111/j.1755-053x.2010. 01133.x 
Bahri, M., St-Pierre, J., \& Sakka, O. (2011). Economic value added: a useful tool for SME performance management. International Journal of Productivity and Performance Management, 60(6), 603-621. doi: 10.1108/17410401111150779

Baran, L. (2017). Director connectedness and firm value in the S\&P 500 Index reconstitutions. Journal of Economics and Business, 92, 63-79. doi: 10.1016/j.jeconbus.2017.06.001

Bohren, O., \& Strom, R. (2010). Governance and Politics: Regulating Independence and Diversity in the Board Room. Journal f Business Finance \& Accounting, 37(9-10), 1281-1308. doi: 10.1111/j.1468-5957.2010. 02222.x

Dawar, V. (2014). Agency theory, capital structure, and firm performance: some Indian evidence. Managerial Finance, 40(12), 1190-1206. doi: 10.1108/mf-10-2013-0275

Detthamrong, U., Chancharat, N., \& Vithessonthi, C. (2017). Corporate governance, capital structure, and firm performance: Evidence from Thailand. Research in International Business and Finance, 42, 689-709. doi: 10.1016/j.ribaf.2017.07.011

Ehi-Oshio, O., Adeyemi, A., \& Enofe, A. (2013). Determinants of Corporate Profitability in Developing Economies. European Journal of Business and Management, 5(16), 42-50.

Faccio, M., Marchica, M. T., \& Mura, R. (2016). CEO gender and corporate risk-taking and the efficiency of capital allocation. Journal of Corporate Finance, 39, 193-209. doi: 10.1016/j.jcorpfin.2016.02.008

Fidanoski, F., Simeonovski, K., \& Mateska, V. (2014). The Impact of Board Diversity on Corporate Performance: New Evidence from Southeast Europe. Corporate Governance in the US and Global Settings, 17, 81-123. doi: http://dx.doi.org/10.1108/S1569$\underline{373220140000017003}$

García-Meca, E., García-Sánchez, I., \& Martínez-Ferrero, J. (2015). Board diversity and its effects on bank performance: An international analysis. Journal of Banking \& Finance, 53, 202-214. doi: 10.1016/j.jbankfin.2014.12.002

García-Sánchez, I., Martínez-Ferrero, J., \& García-Meca, E. (2017). Gender diversity, financial expertise and its effects on accounting quality. Management Decision, 55(2), 347-382.

Gill, A., Biger, N., \& Mathur, N. (2011). The Effect of Capital Structure on Profitability: Evidence from the United States. International Journal of Management, 28(4), 3-15.

Groysberg, B., Cheng, Y., \& Bell, D. (2017). 2016 Global Board of Directors Survey. Spencer Stuart. Retrieved from https://www.spencerstuart.com//media/pdf\%20files/research\%20and\%20insight $\% 20$ pdfs/wcd-board-survey2016 041416.pdf

Hasan, M., Ahsan, A., Rahaman, M., \& Alam, M. (2014). Influence of Capital Structure on Firm Performance: Evidence from Bangladesh. International Journal of Business and Management, 9(5), 184-194. doi: 10.5539/ijbm. v9n5p184 
Hillman, A. J. (2015). Board diversity: Beginning to unpeel the onion. Corporate Governance: An International Review, 23(2), 104-107. Doi:10.111/corg.12090

Hillman, A. J., \& Dalziel, T. (2003). Board of Directors and Firm Performance: Integrating Agency and Resource Dependence Perspectives. The Academy of Management Review, 28(3), 383-396. Doi: 10.2307/30040728

Hu, N., Huang, R., Li, X., \& Liu, L. (2017). The impact of CEOs' accounting backgrounds on earnings management and conservatism. Journal of Centrum Cathedra, 10(1), 4-24. doi: $10.1108 /$ jcc-10-2016-0016

Isidro, H., \& Sobral, M. (2014). The Effects of Women on Corporate Boards on Firm Value, Financial Performance, and Ethical and Social Compliance. Journal of Business Ethics, 132(1), 1-19. doi: 10.1007/s10551-014-2302-9

Le, T., \& Bich, N. (2017). Capital Structure and Firm Performance: Empirical evidence from a developing country. Research in International Business and Finance.

Ness, R., Miesing, P., \& Kang, J. (2010). Board of Director Composition And Financial Performance In A Sarbanes-Oxley World. Academy of Business and Economics Journal, 10(5), 56-74.

Nirajini, A., \& Priya, K. (2013). Impact of Capital Structure on Financial Performance of the Listed Trading Companies in Sri Lanka. International Journal Of Scientific And Research Publications, 3(5), 1-9.

Optimum capital structure |F9 Financial Management | ACCA Qualification | Students | ACCA Global. (2018). Retrieved from http://www.accaglobal.com/my/en/student/examsupport-resources/fundamentals-exams-study-resources/f9/technical-articles/optimumcapital-structure.html

Nassar. (2016). The Impact of Capital Structure on Financial Performance of the Firms: Evidence from Borsa Istanbul. Journal of Business \& Financial Affairs, 5(2), 173. doi: 10.4172/2167-0234.1000173

Salim, M., \& Yadav, R. (2012). Capital Structure and Firm Performance: Evidence from Malaysian Listed Companies. Procedia - Social and Behavioral Sciences, 65, 156-166. doi: 10.1016/j.sbspro.2012.11.105

Siddiqui, S. (2015). The association between corporate governance and firm performance - a meta-analysis. International Journal of Accounting \& Information Management, 23(3), 218-237. doi: 10.1108/ijaim-04-2014-0023

Singh, G. (2013). The interrelationship between Capital Structure and Profitability with Special Reference to Manufacturing Industry in India. International Journal Of Management And Social Sciences Research (IJMSSR), 2(2319-4421), 55-61.

Solimun, S., Fernandes, A., \& Nurjannah, N. (2017). Metode Statistikal Multivariat Pemodelan Persamaaan Struktural Pendekatan WarpPLS. Malang: UB Press. 
Strom, R., D’Espallier, B., \& Mersland, R. (2014). Female leadership, performance, and governance in microfinance institutions. Journal of Banking \& Finance, 42, 60-75. doi: 10.1016/j.jbankfin.2014.01.014

Sultan, A., \& Adam, M. (2015). The Effect of Capital Structure on Profitability: An Empirical Analysis of Listed Firms in Iraq. European Journal of Accounting, Auditing and Finance Research, 3(2), 61-78.

Tsai, M., \& Tung, W. (2014). Corporate governance, resources, FDI commitment, and firm performance. Chinese Management Studies, 8(3), 313-332. doi: 10.1108/cms-08-20120118

Usman, M., Farooq, M. U., Zhang, J., Makki, A. M. M. \& Khan, M. K. (2019). Female directors and the cost of debt: Does gender diversity in the boardroom matter to lenders? Managerial Auditing Journal, 34(4), 374-392. doi: 10.1108/MAJ-04-2018-1863.

Vo, X., \& Ellis, C. (2017). An empirical investigation of capital structure and firm value in Vietnam. Finance Research Letters, 22, 90-94. doi: 10.1016/j.frl.2016.10.014 
The Indonesian Journal of Accounting Research - May, Vol. 23, No.2, 2020

intentionally blank 